\title{
The color of refractory organic carbon
}

\author{
Maxime Debret ${ }^{1, *}$, Yoann Copard ${ }^{1}$, Antonin Van Exem ${ }^{1,2}$, Geneviève Bessereau ${ }^{3}$, Frank Haeseler ${ }^{3}$ \\ and Jean-Noël Rouzaud ${ }^{4}$ \\ ${ }^{1}$ Laboratoire Morphodynamique Continentale et Côtière, UMR CNRS 6143 M2C, Université de Rouen, 76821 Mont-Saint-Aignan, \\ France \\ ${ }^{2}$ Institut des Sciences de la Terre d'Orléans, UMR CNRS 7327 ISTO, 45071 Orléans, France \\ ${ }^{3}$ IFP Energies nouvelles, 92852 Rueil-Malmaison, France \\ ${ }^{4}$ Laboratoire de Géologie de l'École Normale Supérieure, UMR CNRS 8538, 75231 Paris, France
}

Received: 31 October 2017 / Accepted: 24 April 2018

\begin{abstract}
Organic matter studies find an echo within different topics such as biogeochemical cycles, processes occurring in continental surfaces, anthropogenic activities, climate science, earth and planetary sciences, etc. Today's challenges include finding and developing the most appropriate method(s) supporting the differentiation and characterisation of various types of recalcitrant organic matter in modern environments. In this study, we focus on combustion residues and coals as these two types of organic matter contain a significant amount of so-called recalcitrant organic carbon (black carbon and fossil organic carbon). Both these materials are ubiquitous, broadly stem from the same living organisms and have similar polyaromatic structures. In this respect, we tested a spectrophotometry method, classically used for sedimentology, as a very fast method for preliminary investigations. Analyses were performed with a wide range of standards and referenced samples. The results discriminate three different spectral signatures related to the degree of transformation of organic matter related to the degree of aromaticity (i.e. carbonisation). Using calibration curves, total organic carbon content can be estimated in experimental mixes with mineral matter and in a real context using subsurface sample (Gironville 101 borehole, Paris Basin, France). This method has particularly high sensitivity to very low organic matter content and is shown to be promising for a rapid evaluation of the organic carbon content.
\end{abstract}

Keywords: black carbon / fossil organic carbon / spectrophotometry / carbonisation / total organic carbon

Résumé - La couleur du carbone organique réfractaire. Les études sur la matière organique trouvent un écho dans différents sujets tels que les cycles biogéochimiques, les processus sur les surfaces continentales, les activités anthropiques, les sciences du climat, les sciences de la Terre et des planètes, etc. Les défis actuels comprennent la recherche de méthodes de différenciation et de caractérisation de divers types de matière organique réfractraire dans les environnements modernes. Dans cette étude, nous nous concentrons sur les résidus de combustion et les charbons géologiques car ces deux types de matières organiques contiennent une quantité importante de carbone organique dit réfractaire (black carbon et carbone organique fossile). Ces deux matériaux omniprésents, proviennent en grande partie des mêmes organismes vivants et ont des structures polyaromatiques similaires. À cet égard, nous avons testé une méthode de spectrophotométrie, classiquement utilisée pour la sédimentologie, comme méthode très rapide pour les investigations préliminaires. Les analyses ont été effectuées avec un large éventail d'échantillons standards et référencés. Les résultats discriminent trois signatures spectrales différentes liées au degré de transformation de la matière organique en rapport avec le degré d'aromaticité (c'est-à-dire la carbonisation). En utilisant des courbes d'étalonnage, la teneur en carbone organique total peut être estimée dans des mélanges expérimentaux avec des matières minérales et dans un contexte réel en employant des échantillons souterrains (forage Gironville 101, bassin de Paris, France). Cette méthode est particulièrement sensible à la très faible teneur en matière organique et s'avère prometteuse pour une évaluation rapide de la teneur en carbone organique.

\footnotetext{
*Corresponding author: maxime.debret@univ-rouen.fr
} 


\section{Introduction}

In continental surfaces, organic matter (OM) exhibits various origins such as recent $\mathrm{OM}$ (e.g. soil OM, aquatic $\mathrm{OM}$ ), combustion residues (in this study referred to as black carbon materials, $\mathrm{BCM}$, i.e. derived from plants (wild) fire and fuel combustion, Kuhlbusch, 1998) and fossil organic matter (FOM) released by erosion and weathering of outcropping sedimentary rocks (Copard et al., 2007). Among these three $\mathrm{OM}$ categories, $\mathrm{BCM}$ and $\mathrm{FOM}$ can contain a significant amount of organic carbon (OC), called black carbon (BC) and fossil OC (FOC), respectively, which is assumed roughly to be highly resistant to weathering; hence they are ubiquitous in a number of environments (for BCM, see Schmidt and Noack, 2000; for FOM, see Copard et al., 2007). On the whole and whatever the OM carbonisation processes (diagenesis or incomplete combustion), the resistant character of OC increases with the enrichment in $\mathrm{C}$ content associated with a loss of heteroatoms, mainly oxygen and hydrogen (e.g. Durand, 1980; Hedges et al., 2000; Masiello, 2004) leading to a progressive aromatisation (i.e. carbonisation) of OM. Accordingly, for the combustion residue, the resistant nature of $\mathrm{OC}$ increases with the intensity of combustion and ranges from charcoal to condensed particles (i.e. soot; Kuhlbusch, 1998). The resistance of OC increases with the maturity of FOM, which depends of the geodynamic context (burial, geothermal gradient), and of the kerogen origins (I, II, III) controlling the FOM chemistry and its further transformation (e.g. rate) during thermal processes. As a consequence, each kerogen type shows a thermal trend as seen in a Van Krevelen diagram (Fig. 1) and their transformations tend towards an enrichment in some polyaromatic materials depleted in $\mathrm{H}$ and $\mathrm{O}$, previously released into $\mathrm{CO}_{2}, \mathrm{H}_{2} \mathrm{O}$ and hydrocarbons during heating (i.e. from diagenesis (s.s.) to methagenis, (e.g. Durand, 1980). For the lower degrees of thermal evolution (diagenesis), FOM resistance toward weathering is governed by its chemical composition, inherited from the biological precursors and modified by processes undergone before burial.

The more recalcitrant is the $\mathrm{OM}$, the more likely is $\mathrm{OM}$ preservation and storage in recent sediments or soils. FOM and $\mathrm{BCM}$ can hold some useful but different information such as anthropogenic activities (Goldberg, 1985), climatic changes (Knicker, 2011), the biogeochemical C cycle (Lehmann et al., 2008; Graz et al., 2012), as well as erosion and weathering processes (Noël et al., 2001). In sediments or soils, although it is assumed that recent OM can be easily discriminated from FOM using bulk geochemical (e.g. Copard et al., 2006), isotopic (e.g. Raymond and Bauer, 2001) and optical (e.g. Graz et al., 2010) methods, part of this recent and non-carbonized OM still remains uncharacterised (e.g. Hedges et al., 2000; Burdige, 2007) and could potentially mimic BCM and FOM signatures (e.g. Hammes et al., 2008). Likewise, deciphering the signatures of each $\mathrm{OM}$ source also requires isolating BCM from FOM, which together are characterised as recalcitrant and show a similar geochemical signature (e.g. Hedges et al., 2000). As a consequence, discrepancies may arise during the characterisation and quantification of $\mathrm{BCM}$ in soils and sediments (e.g. Dickens et al., 2004). The main reason for this confusion is that:

- part of BCM and coals (FOM) frequently have the same biological precursor (terrestrial plants);

- both these materials experienced a carbonisation process leading to a progressive aromatisation of the carbonaceous residue.

From a qualitative point of view, some optical techniques such as palynofacies are used to isolate pyrogenic particles $(e$. $g$. charcoal seen as an opaque debris with devolatilisation vacuoles) from an organic mixture within sediment or soil (Vannière et al., 2008). From a quantitative viewpoint, complex methods such as (i) chemo-thermal oxidation (ii) acid dichromate oxidation, (iii) sodium chlorite oxidation, (iv) thermogravimetry coupled with differential scanning calorimetry, (v) UV photo-oxidation, (vi) benzene polycarboxylic acids (BPCAs), (vii) thermal/optical transmittance and reflectance (from (i) to (vii) see Hammes et al., 2007 and references therein), (viii) ruthenium tetroxide oxidation (Quénéa et al., 2005) and (ix) radiocarbon analysis (e.g. Dickens et al., 2004) are used to isolate BCM and quantify the $\mathrm{BC}$ borne by this material. However, data from measurements using these different techniques are difficult to compare (Hammes et al., 2008). Recently, new but complex methods have arisen for the characterisation of $\mathrm{BC}$, such as transmitted electron microscopy (TEM) coupled with an EDX probe (Kuo et al., 2013), recoupled long-range dipolar dephasing solidstate ${ }^{13} \mathrm{C}-\mathrm{NMR}$ (Ding and Rice, 2012) or hydropyrolysis (Meredith et al., 2012). Other studies have also attempted to combine certain spectroscopic and thermal methods to differentiate soot from char particles with highly limited FOC characterisation (Roth et al., 2012). More recently, molecular (BPCAs), spectroscopic (FTIR) and pyrolysis (Rock-Eval 6 pyrolysis) methods have been coupled in order to differentiate BC sources in a soil (Wolf et al., 2013). However, with the exception of trials on Rock-Eval pyrolysis (Poot et al., 2009), the complexity of these methods prevents their use as routine methods to distinguish $\mathrm{BC}$ and $\mathrm{FOC}$ from other OC.

To this end, we explored a spectrophotometry method and related developments as a useful tool for a rapid identification of carbon components. Indeed, spectrophotometry is a very useful and promising tool, classically used on board research vessels and for land-based measurement to quantify sediment colour (see Debret et al., 2011 for a review). This device allows rapid and non-destructive measurements directly on sediment. A few studies have already attempted to apply the colour measurement for carbon quantification and characterisation purposes, but the results were not conclusive because they were restricted to the classical colour parameter. For example, Deaton et al. (1996) address the problem of OM maturity by evaluating conodont (microfossils) colour by spectrophotometry. Hammes et al. (2008) used the L* parameter (black/ white) to distinguish different kinds of $\mathrm{BC}$, but this method remains inconclusive. In a recent publication, Van Exem et al. (2018) propose to evaluate the presence of black carbon with hyperspectral imaging. Here we propose powerful method, based on the pioneering publication of Debret et al. (2011) especially designed for this type of study. Indeed, these authors 


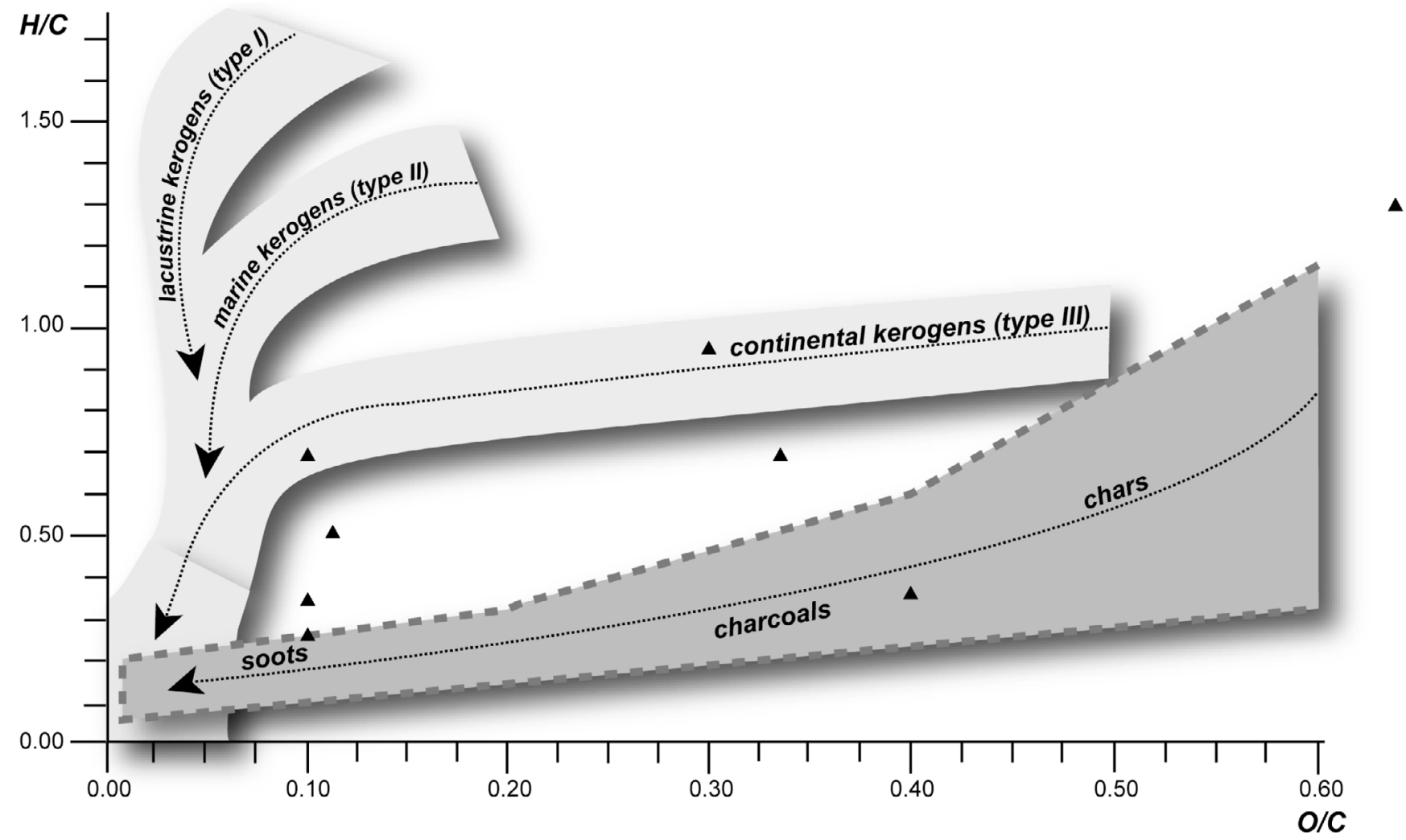

Fig. 1. Kerogens limits within the Van Krevelen diagram. In dash, approximative limits currently admitted for $(\mathrm{H} / \mathrm{C})_{\text {at. }}$ and $(\mathrm{O} / \mathrm{C})_{\text {at. }}$ ratio values of BCM: $\quad(\mathrm{H} / \mathrm{C})_{\text {at. }}$ ratio values $\left(0.02<\right.$ soot $<0.30<$ charcoals $<0.60<$ chars $<1.00$, Hammes et al., 2007), $(\mathrm{O} / \mathrm{C})_{\text {at. }}$ ratio values $(0.10<$ soot $<0.20<$ charcoals $<0.40<$ chars $<0.60$, Godlberg, 1985 in Hedges, 2000, Hammes et al., 2007). In black triangle: various natural or experimental charcoals, fossil charcoals (Kuhlbusch, 1998). Black arrows direction indicates the elemental composition change with increasing thermal processes (during burial and during combustion).

produced a Q7/4 diagram taking into account the slope of the visible spectrum (VIS) versus brightness (L* white/black) for a given sample. Combined with first derivative spectra (FDS) of the raw spectra, six end-members related to sediment composition can be identified. Among them, three describe mineralogical composition (iron-rich deposits, clear deposits, clayey deposits) and the three others designate organic endmembers: chlorophyll a and by-products, melanoidin type and altered organic matter. Samples from coals, charcoals and soot are located in the altered organic matter end-member but, until now, it is impossible to discriminate them using the raw spectrum. Based on a high number of standards, we address this problem by developing a new method to disentangle the complexity of these recalcitrant organic matter signatures. Among them, coal samples covering a large range of maturity (from lignite to meta-anthracite), BCM samples covering a large range of combustion (from charcoal to soot), samples previously recommended by the International Steering Committee for Black Carbon Reference Materials and natural or synthetic samples for which geochemical characteristics have already been published, were analysed in this study.

After a calibration of the method on standards, the spectral signature of the fossil organic matter in various mineral matrices was investigated. We followed the recommendations of Hammes et al. (2008) to test the reliability of the methods, indicating that future studies dealing with $\mathrm{BC}$ should use the same materials for future methodological improvements and development of novel analytical approaches.

\section{Material and methods}

\subsection{Samples and sample processes}

In order to develop, test and validate our methodology, various natural (30 coals, 1 graphite, 1 charcoal) and synthetic previously crushed samples (14 charcoals, 1 coke, 1 soot, 1 graphite, 1 pyrolysed coal) were selected. Geochemical (atomic ratio) and optical characteristics (vitrinite reflectance) and experimental conditions (for synthetic samples) of some of these samples have already been published (Tab. 1 and associated references). Five samples correspond to standards that have been previously recommended by the International Steering Committee for Black Carbon Reference Materials (http://www.geo.uzh.ch/en/units/2b/Services/BC-material. htmL) and others come from two combustion experiments on eucalyptus wood (12 samples; see Trompowsky et al., 2005, for further details). Natural humic coal samples encompass a wide range of thermal maturity, from lignite to the meta-anthracite rank from La Mure coalfield (Tab. 1). Three sets of samples have particularly retained our attention. The first concerns the A23/A23-590 combination where A23 was picked up at outcrop in the Ales coalfield (Airolles seam, 
Table 1. Main characteristics of samples. Atomic ratios for Upper Carboniferous coals from France are given in Copard (2002), for Eucalyptus chars in Trompowsky et al. (2005). Vitrinite reflectance and atomic ratios values of coal samples from Gironville (GIR) are calculated from the compilation of Rouzaud et al. (1991).

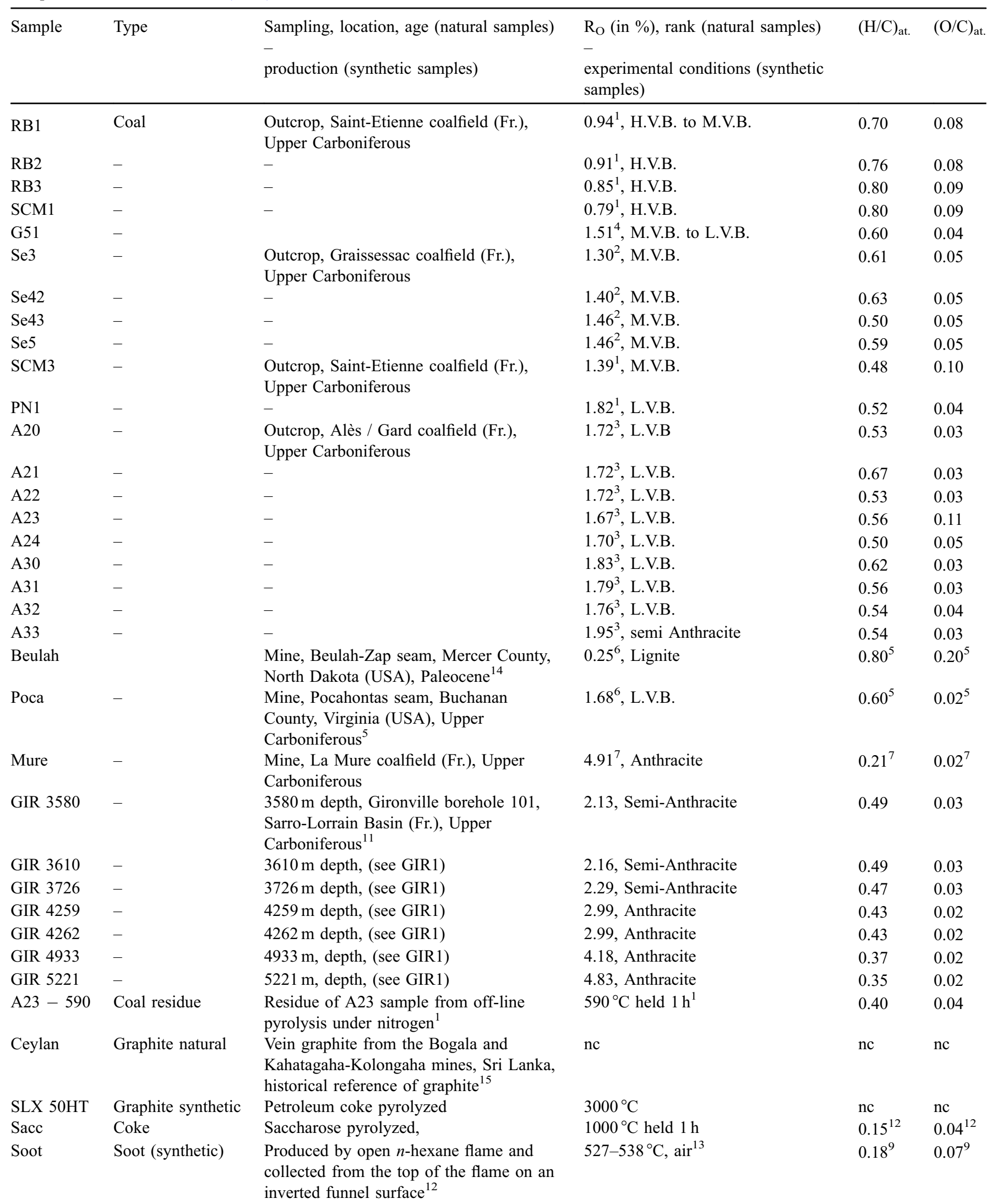


Table 1. (continued).

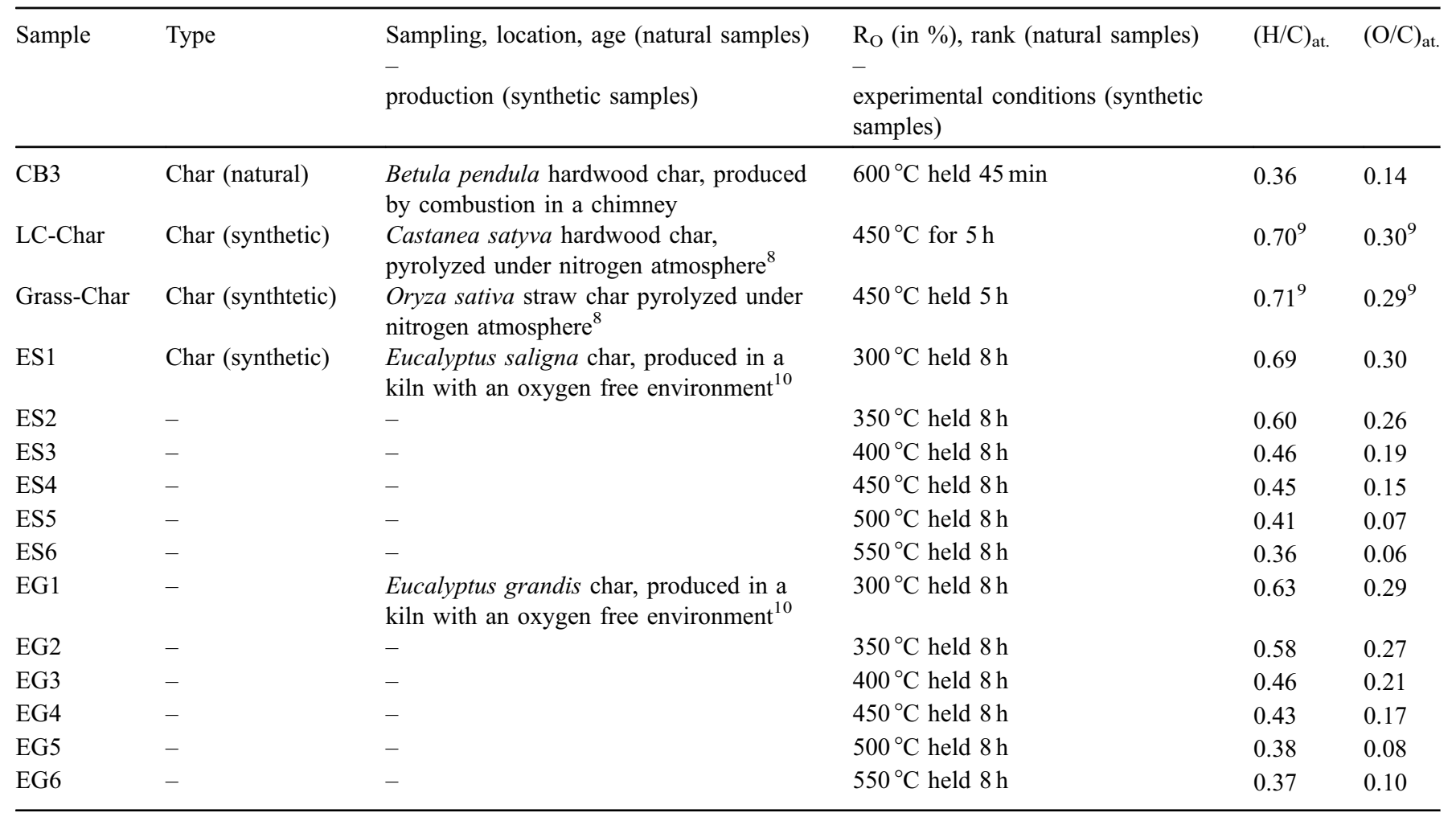

References related to samples (measurements, experimental conditions):

1: Copard (2002); 2: Copard et al. (2000); 3: Copard et al. (2002);4: Copard et al. (2004); 5: Vorres (1990); 6: Busch et al. (2003); 7: Duber et al. (2000); 8 Hammes et al. (2007); 9: Hammes et al. (2008); 10: Trompowsky et al. (2005); 11: Rouzaud et al. (1991); 12: Rouzaud and Oberlin (1990); 13: Akhter et al. (1985); 14: Nichols (1999); 15: Bernal (1924).

Sainte-Barbe beam, France), where 590 indicates the pyrolysis temperature (in ${ }^{\circ} \mathrm{C}$ ) held for $1 \mathrm{~h}$ (Copard, 2002). The second pair, SCM1/SCM3, involves outcropping samples from the Saint Etienne coalfield (Assises d'Avaize, Grande Couche Béraudière, France) where the SCM3 sample was taken in the same layer as SCM1 but exhibits a significantly higher rank $(\mathrm{Ro}=1.39 \%)$ than its counterpart SCM1 $(\mathrm{Ro}=0.79 \%)$. The most probable assumption explaining this difference in degree of maturity is that SCM3 was submitted to a pit fire at outcrop (i.e. after its coalification; Copard, 2002). The last set corresponds to seven coals from the Gironville 101 borehole (Sarro-Lorrain basin, France) sampled at 3580 to 5221-m depths. These samples were previously subjected to acid attacks $(\mathrm{HCl} / \mathrm{HF})$ before analyses. Atomic ratios and vitrinite reflectance values are adopted from Alpern (1966) and samples range from semi-anthracite to meta-anthracite (Tab. 1).

The detection limits of spectrophotometric signatures were evaluated using an experimental design consisting of a signal dilution of the refractory $\mathrm{OM}$ within two mineral-based matrices (chalk and illite) showing contrasting colours (white versus dark green). These matrices are frequently mixed with $\mathrm{OM}$ in sediments (i.e. carbonate vs. detrital end members). Because of the amount of samples available, we focused on the A20 sample (rank: low volatile bituminous; Tab. 1) from the Ales coalfield. Each sample was reduced to very fine powder, to avoid a possible effect of particle size and mixed with the matrix to obtain carbon concentrations ranging from 1 to ca. 80 wt.\%. For the method's implementation phase, we used a series of samples from the Gironville 101 borehole (SarroLorrain basin) stored at the French Institute of Petroleum New Energy (IFPEN) and then powdered. These samples have also been used as a reference for the study of diagenesis, catagenesis and metagenesis of humic coals (Alpern, 1966; Rouzaud et al., 1991). Thirty-two samples of raw rock corresponding to a depth between 1160 and $3440 \mathrm{~m}$, and for which TOC values were already measured at IFPEN with a Rock-Eval 2 pyrolyzer (unpublished data), were used for this purpose.

\subsection{Spectrophotometry}

A handled Minolta CM 2600d spectrophotometer was used to measure the samples' reflectance intensity of visible wavelengths between 400 and $700 \mathrm{~nm}$, at 10-nm intervals. The spectrophotometer is composed of a sphere with a surface coated with barium sulphate. The light source is positioned at the entrance of the sphere ( 5 or $8 \mathrm{~mm}$ in diameter) and the light emitted is reflected in all directions. This sphere is called an integrating sphere because it projects light onto the sample in all directions at a constant rate. This eliminates any measurement irregularities due to shadow zones and surface faults. The wavelengths considered belong to the extended visible domain (from 400 to $700 \mathrm{~nm}$ ). In addition, the sensitivity of the device allows breaking down the wavelength spectrum into $10-\mathrm{nm}$ steps. The light emitted by the light source can be set to different types of illuminants; we used 
D65, which corresponds to a temperature of $6504 \mathrm{~K}$, i.e. daylight. We adopted Specular Component Excluded mode CIE L* a* $b^{*}$ analysis in order to avoid biasing data with specular reflection. The $L^{*} a^{*} b^{*}$ mode covers the entire spectrum perceptible to the human eye and it includes every colour mode (RGB and CMYK). L* corresponds to brightness (white/black), $\mathrm{a}^{*}$ is the red/green axis and $\mathrm{b}^{*}$ is the blue/yellow axis. The aperture of the instrument was $8 \mathrm{~mm}$. Contrary to the methodology of Chapman and Shackleton (1998), who recommend covering the instrument to be calibrated by the white standard with polyethylene film, we calibrated the spectrophotometer without the film as the instrument expects specific reflectance values that are stored in its internal memory (Balsam et al., 1997; Debret et al., 2006; 2011).

Each sample was measured three to five times on different locations to ensure reproducible measurements and their representativeness. The measurements were taken on a previously powdered sample. In order to avoid possible atmospheric pollution (dust), a protective windowpane that does not change the spectrum signal (provide by Konica Minolta), was systematically used. The spectra presented in this study correspond to an average of the measurements processed on the samples.

\subsection{Rock Eval pyrolysis}

The geochemical signature of the samples was acquired using Rock-Eval 6 pyrolysis (RE6, Vinci Technologies). Previously developed for petroleum purposes and the analysis of sedimentary rocks (e.g. Lafargue et al., 1998), the method has now been successfully tested for recent OM in matrices such as soils (Di-Giovanni et al., 1998; Noël et al., 2001) and suspended sediments in rivers (Copard et al., 2006).

RE6 pyrolysis comprises two successive analytical stages performed with a heating rate of $25^{\circ} \mathrm{C} \mathrm{min}^{-1}$. The first step consists of pyrolysis of $30 \mathrm{mg}$ of previously crushed sample in an oven under an inert atmosphere. Pyrolysis effluents are carried by nitrogen. Hydrocarbons and oxygenate compounds yielded over a temperature range of $200-650{ }^{\circ} \mathrm{C}$ are quantified with flame ionisation and infrared detectors, respectively. The second step consists of the oxidation, in a second oven, of the pyrolysed carbonaceous residue between $400^{\circ} \mathrm{C}$ and $750{ }^{\circ} \mathrm{C}$ in air $\left(\mathrm{N}_{2} / \mathrm{O}_{2} ; 80 / 20\right)$

Among the parameters delivered by this analytical method, we focused both on the hydrogen index (HI, in $\mathrm{mg}$ $\left.\mathrm{HC} \mathrm{g}^{-1} \mathrm{TOC}\right)$, defined as an indicator of the hydrogen richness and on the oxygen index (OI RE6, in $\mathrm{mg} \mathrm{O}_{2} \mathrm{~g}^{-1}$ TOC), defined as an indicator of the oxygen richness of the analysed sample. The amount of organic carbon is given by the total organic carbon (TOC, expressed in wt.\%), equal to the sum of the pyrolysed $\mathrm{OC}$ and the residual organic carbon provided by the oxidation step. Uncertainties in HI, OI and TOC values are \pm 5 , 17 and $3 \%$, respectively (Noël, 2001).

\subsection{Elemental analyses}

Elemental analyses of $\mathrm{C}, \mathrm{H}, \mathrm{O}$ essential to obtain $\mathrm{H} / \mathrm{C}((\mathrm{H} /$ $\left.\mathrm{C})_{\text {at. }}\right)$ and $\mathrm{O} / \mathrm{C}\left((\mathrm{O} / \mathrm{C})_{\text {at. }}\right)$ atomic ratios were performed at the Department of Central Analysis Service of the CNRS (SCA, UMR 5280, Lyon). Classic comparison of these two ratios in a

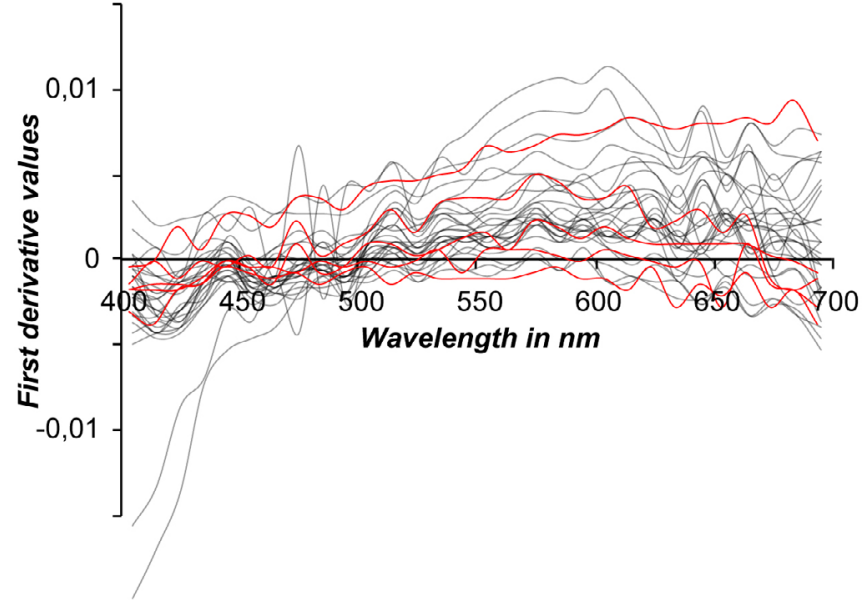

Fig. 2. First derivative spectra (FDS) of the samples used in this study, red spectra correspond to BC signal, Black spectra to FOC.

Van Krevelen diagram leads to the recognition of the main types of OM (lacustrine, marine, terrestrial). This diagram also makes it possible to follow the chemical changes of OM during thermal and/or oxidative processes (Durand, 1980). These two atomic ratios may be respectively correlated with $\mathrm{HI}$ and OI from RE6 pyrolysis (Bordenave et al., 1993).

Analyses of $\mathrm{C}$ and $\mathrm{H}$ is a complete combustion of sample at $1080{ }^{\circ} \mathrm{C}$ under helium and oxygen. These two elements are converted into $\mathrm{CO}_{2}$ and $\mathrm{H}_{2} \mathrm{O}$, respectively, which are then separated on a chromatographic column and measured using a thermal conductivity detector. These gases are quantified with specific IR detectors for $\mathrm{CO}_{2}$ and $\mathrm{H}_{2} \mathrm{O}$. Oxygen was quantified by pyrolysis at $1080^{\circ} \mathrm{C}$ under a nitrogen purge in which oxygen is converted to $\mathrm{CO}$ by passage over activated carbon at $1120^{\circ} \mathrm{C}$. $\mathrm{CO}$ is then quantified using a specific IR $\mathrm{CO}$ detector. For each of these thermal degradations, a few milligrams of powdered sample are sufficient. Uncertainties (absolute \%) on the measurement of $\mathrm{C}, \mathrm{H}$ and $\mathrm{O}$ are $0.4,0.2$ and $0.3 \%$, respectively.

\section{Results and discussion}

\subsection{OM spectral signature}

\subsubsection{First derivative spectra (FDS)}

Typical values of CIELab referential, $L^{*}, a^{*}$ and $b^{*}$ cannot be used here to identify the origin of organic matter because the samples are mainly Pure Organic Matter (POM) and The L* values result from mixing functions integrating different wavelengths not necessarily specific to OM $(600-700 \mathrm{~nm}$; Balsam et al., 1997). However $L^{*}$ is very helpful to consider the quantify the TOC as shown in Figure 7, Section 3.3. A classically used method in colour analysis consists in taking the first derivative values of raw colour spectra (FDS) to identify the origin of colour in measured materials (e.g. Ji et al., 2005). With this mathematical method, it is possible to amplify variations of raw spectra (Fig. 2). Thus, between 600 and $700 \mathrm{~nm}$, the OM region (Balsam et al., 1997), we observed:

- spectra with positive first derivative values: increasing raw spectra (reflectance increases as wavelength increases) (e.g. Grass-char, Beulah, Poca); 

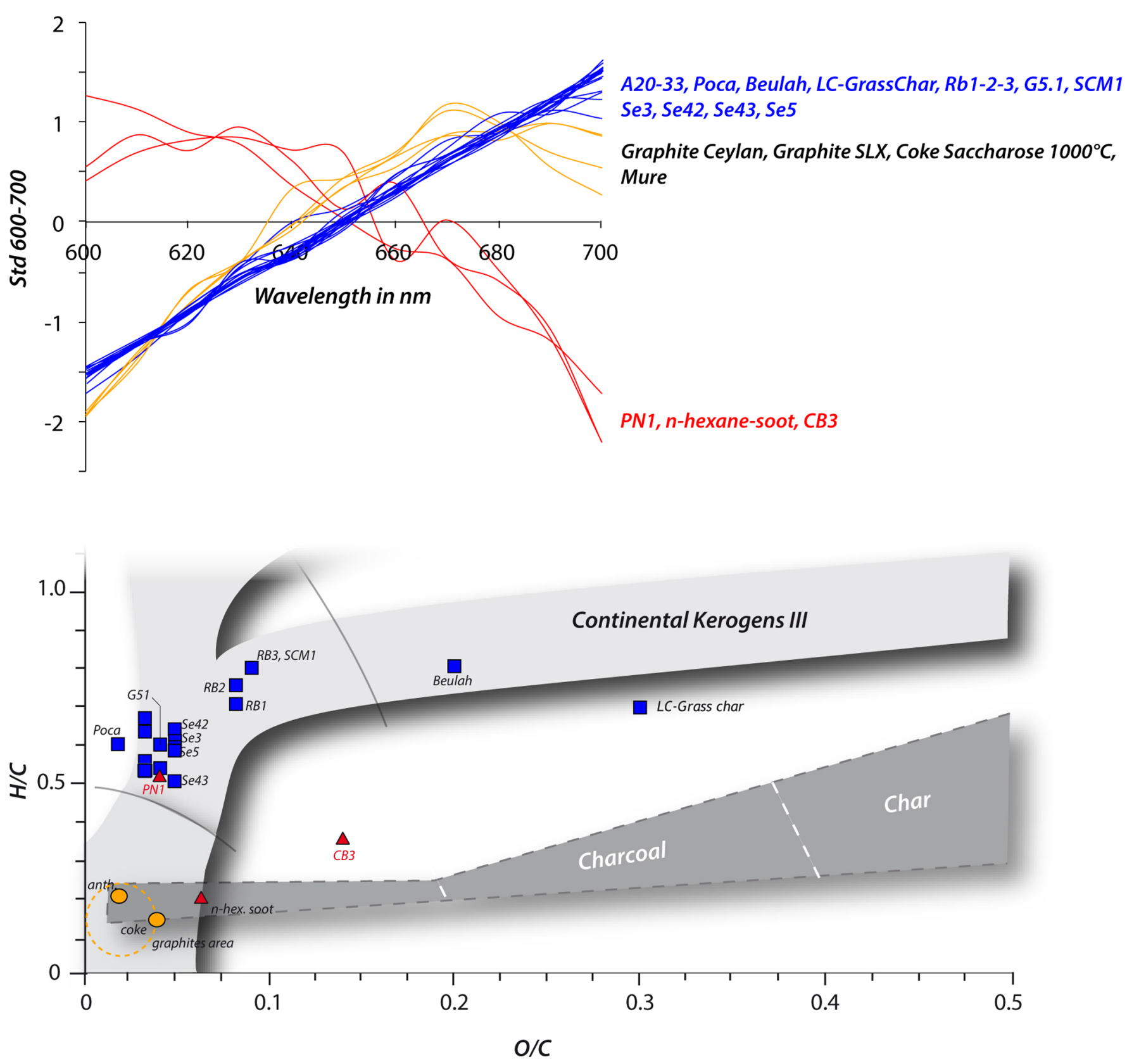

Fig. 3. Standardized spectra reveal three signatures (upper part) visible in the Van Krevelen diagram (lower part) with a singular limit for (H/C) ${ }_{a t}$ ratio value of 0.50 . Upper this limit (with an unknown $(\mathrm{O} / \mathrm{C})_{\text {at. }}$ limit value, in blue signals), the Std spectra systematically increase while decrease when lower than 0.50 (red signals). A third signature (orange signals) with increasing and decreasing slope is also evidenced between the region $670-700 \mathrm{~nm}$ and corresponds to samples with very low $(\mathrm{H} / \mathrm{C})_{\text {at. }}-(\mathrm{O} / \mathrm{C})_{\text {at. }}$ ratio values.

- spectra with negative values and therefore decreasing FDS: decreasing raw spectra (reflectance decreases as wavelength decreases) (e.g. LC Char, SCM3);

- spectra with intermediate values with variable slopes (e.g. Rb1, PN1).

Clearly, the FDS method does not discriminate BCM from FOM signatures. However, the signals can be differentiated according to their slope in the 600 - to $700-\mathrm{nm}$ range (Fig. 2).

\subsubsection{Standardized (Std) signals}

To emphasise the slope differences of colour spectra in the OM spectral range, the spectra were standardized between 600 and $700 \mathrm{~nm}$. This signal treatment highlights three types of signals (Fig. 3):

- a population characterised by a incrinsing spectrum (e.g. Beulah, Poca, most samples from Alès and Saint Etienne coalfields, LC Char, Char-Grass);

- a population characterised by a decreasing spectrum (e.g. $n$-hexane soot, CB3, SCM3, PN1); 
- a population characterised by a growing spectrum between 600 and $670 \mathrm{~nm}$ and then gradually showing a negative slope between 670 and $\mathrm{nm}$ (e.g. natural graphite from Ceylon, SLX 50HT synthetic graphite, saccharose-based coke, anthracite from La Mure coalfield): the common feature of these samples is their high aromaticity.

The first case includes a majority of coal samples showing a lower rank ( $c f$. vitrinite reflectance value threshold of 1.80$1.85 \%$, Tab. 1, for details about this threshold, see Sect. 4.1) than that of the PN1 sample and two BCM samples (Grass Char, LC Char). The second concerns a majority of samples subjected to combustion and a high rank coal (PN1, see Tab. 1). The last group encompasses a number of highly mature samples either experienced metagenesis (an anthracite sample from La Mure coalfield) or to a slight metamorphism (natural graphite sample from Ceylon) and to pyrolysis performed at a high temperature (saccharose-based coke and SLX 50HT samples carbonised at 1000 and $3000{ }^{\circ} \mathrm{C}$ respectively; see Tab. 1). Regarding the samples' origin and their distribution into these three clusters, this method is not fully adequate to discriminate BC from FOC. However, the position of the samples in the van Krevelen diagram (Fig. 3) reveals further arguments for discussion. Indeed, although centring and reducing the spectra do not discriminate $\mathrm{BC}$ from $\mathrm{FOC}$, this method can differentiate samples which have a $(\mathrm{H} / \mathrm{C})_{\text {at }}$ ratio close to 0.50 (with PN1 showing a value of 0.52 ). Above this limit, the standardized spectra are strictly increasing, while below, two other types of decreasing signatures are observed. As a consequence, this limit may distinguish some samples derived from a severe combustion or thermal degradation $\left((\mathrm{H} / \mathrm{C})_{\text {at. }}<0.50\right)$ during metagenesis (anthracite from the La Mure coalfield), metamorphism (Ceylon graphite) and pyrolysis (e.g. saccharose-based coke, SLX 50HT), from other samples subjected to a lower thermal degradation during diagenesis/catagenesis $\left((\mathrm{H} / \mathrm{C})_{\mathrm{at}} \cdot>0.50\right)$ and to a low to medium pyrolysis temperature $\left(450^{\circ} \mathrm{C}\right)$ held for a short time (LC and Grass-Char samples). In detail, the atomic ratios (Fig. 3 ) of the $n$-hexane soot sample are close to those produced by saccharose-based coke, contrary to their spectral signature. The origin of this difference could be inherited from the combustion temperature undergone by these samples, where a lower temperature was applied to $n$-hexane soot (i.e. between 500 and $800^{\circ} \mathrm{C}$; Akhter et al., 1985) while reaching $1000{ }^{\circ} \mathrm{C}$ for the coke sample (with the duration of pyrolysis to consider).

The Std method can therefore discriminate different $\mathrm{OM}$ signals not directly based on the type heating process (combustion or maturation during burial) but rather on the time and temperature conditions of the carbonisation process. These conditions control the OM chemistry, highlighted in spectrophotometry by a change in slope of Std signals, corresponding to a $(\mathrm{H} / \mathrm{C})_{\text {at }}$ ratio close to 0.50 . This value is remarkable as it corresponds to the boundary between oil and gas windows, at the level called "semi-coke" or semi-natural coke for pyrolyzates and highly evolved coal, respectively (Rouzaud and Oberlin, 1990).

\subsection{Thermal transformation of OM and spectrophotometric signals}

Among the measured samples, two pairs of samples were used to test the change of spectral signatures according to the degree of thermal transformation recorded by OM. These are (SCM1/SCM3) for the combustion process and (A23/ A23-590) for pyrolysis (see Tab. 1 for details and Sect. 2.2).

Among the measured samples, two pairs of samples were used to test the change of spectral signatures according to the degree of thermal transformation recorded by OM. These are (SCM1/SCM3) for the combustion process and (A23/ A23-590) for pyrolysis (see Tab. 1 for details and Sect. 2.2) (Fig. 3).

For the (SCM1; SCM3) pair, SCM3 corresponds to the SCM1 sample (i.e. the same coal seam from the Saint Etienne coalfield), which was subjected to a partial combustion at high temperatures during a natural pit fire. The Std method applied to spectrophotometric spectra clearly highlights this natural combustion process where the SCM1 signal is increasing and SCM3 decreasing (Fig. 4). The only difference between these two samples is that SCM3 has recorded a higher temperature and consequently a change in chemical composition and structure accompanied by a higher vitrinite reflectance value than SCM1. This is in perfect agreement with the values of the $(\mathrm{H} / \mathrm{C})_{\text {at }}$ ratio, which are on both sides of the 0.50 limit (Figs. 3 and 5). For the (A23; A23-590) pair, the A23-590 sample is the residue of an off-line pyrolysis of the A23 sample at $590^{\circ} \mathrm{C}$ held for $20 \mathrm{~min}$ under nitrogen flux (Copard, 2002). Here again, the spectrophotometry method shows a change in the slope of the Std spectra subsequent to a change in the chemistry of A23 samples after pyrolysis (Fig. 4). As seen for the previous pair, this is in perfect agreement with the $(\mathrm{H} / \mathrm{C})_{\text {at }}$ ratio of these samples in the van Krevelen diagram (Figs. 3 and 5). These results confirm that there is a major change in reflectance measurements in relation to the degree of carbonisation recorded by the kerogen.

If these two pairs highlight the effect of temperature on the shape of the Std signals, the key moment of change in the spectral signature would be verified with the seven samples from the Gironville 101 borehole submitted to an increasing metagenesis, and with two series of samples submitted to a progressive increase in temperature pyrolysis. For the seven coals, the Std signals grow at a 3610-m depth but decrease at $3580 \mathrm{~m}$, meaning that for these two "shallower" samples, the shift in Std signal slopes is probably already reached with an $(\mathrm{H} / \mathrm{C})_{\text {at }}$ ratio close to 0.50 (Tab. 1, Figs. 3 and 5). Deeper, the Std signals systematically decrease (Figs. 3 and 5). Here again, for this natural and ideal example (i.e. samples buried without significant further deformation; see Rouzaud et al., 1991), the moment of this shift occurring for an $(\mathrm{H} / \mathrm{C})_{\text {at. }}$ ratio value close to 0.50 is in perfect agreement with the shift from oil to gas windows and the natural "semi-coke" state (Rouzaud and Oberlin, 1990). In addition, two sets of Eucalyptus grandis and Eucalyptus saligna samples were also used for which experimental conditions of carbonisation have been already described (Trompowsky et al., 2005; Tab. 1). Whatever the series, the spectrophotometry shows Std signatures strictly increasing for temperatures ranging from 300 to $350{ }^{\circ} \mathrm{C}$ and then the signal decreases between 670 and $700 \mathrm{~nm}$ at $450{ }^{\circ} \mathrm{C}$ (Fig. 5). This change is reflected in the Van Krevelen diagram by a $(\mathrm{H} / \mathrm{C})_{\text {at }}$ ratio close to 0.50 and an $(\mathrm{O} / \mathrm{C})_{\text {at }}$ ratio around 0.22 . This change reinforces our previous assumption about the limit at 0.50 for the $(\mathrm{H} / \mathrm{C})_{\text {at }}$ ratio. All things being equal, it is therefore possible to coincide this change in reflectance properties with a major physico-chemical rearrangement 


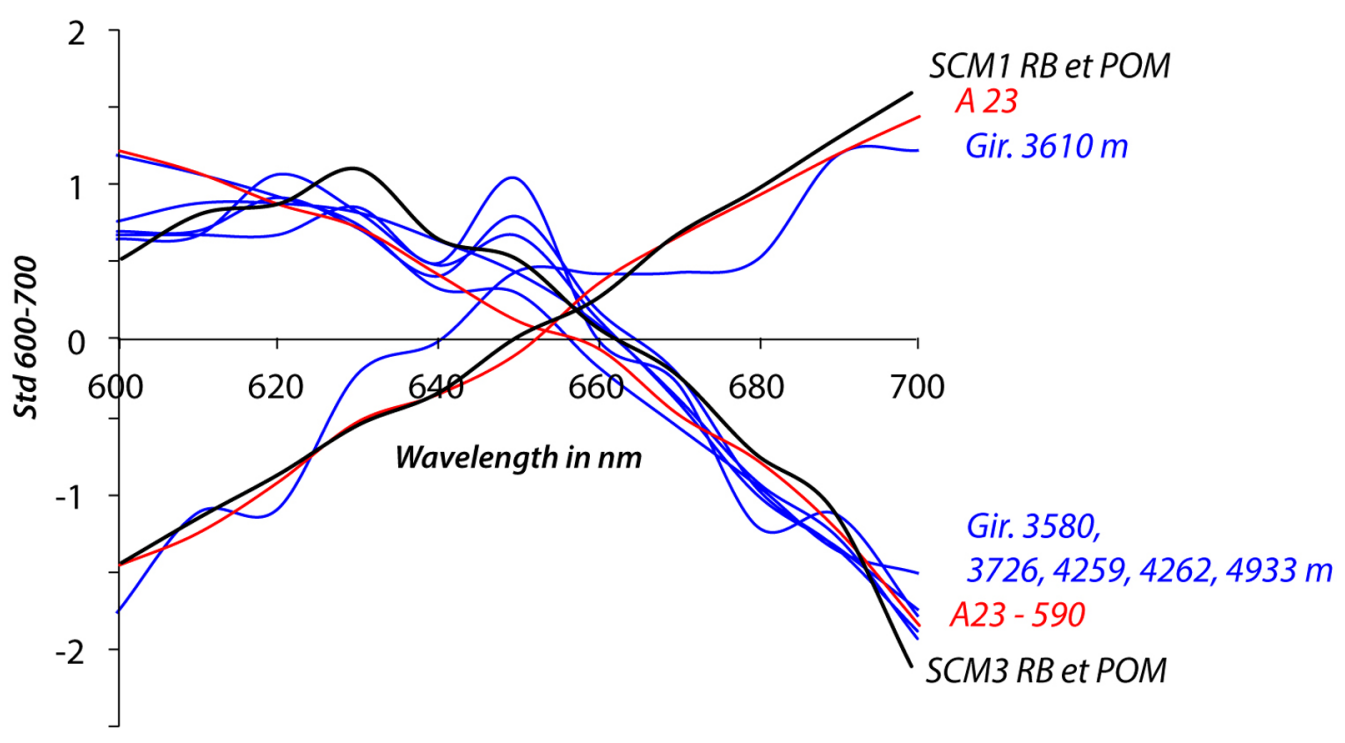

Fig. 4. Increasing Std spectra for coal samples from Ales (A23), Saint-Etienne (SCM1) and Sarro-Lorrain (GIR 3610) coalfields. After a considered carbonisation process (pyrolysis for A23, pit-fire for SCM1 and thermal degradation during burial for GIR 3580), decreasing Std spectra are well evidenced. Colour codes (accompanied by specified symbols) are referred to Figure 3.

within the sample occurring in the neighbourhood of the $(\mathrm{H} / \mathrm{C})_{\mathrm{at}}$ ratio value of 0.50 . This rearrangement is an important step during the carbonisation stage, commonly called "semicoke", occurring just after the maximum liquid hydrocarbons release and corresponding to the onset of the preferential orientation of basic structural units (i.e. stacks of a few nanometre-sized aromatic sheets, Rouzaud and Oberlin, 1989). Depending on the chemical nature of the precursors, the semicoke stage starts between 400 and $500^{\circ} \mathrm{C}$ (Oberlin et al., 1980).

Along with the change of heating conditions, this explains why the LC and Grass-Char standards, produced after a pyrolysis not exceeding $450^{\circ} \mathrm{C}$ for $5 \mathrm{~h}$ (Hammes et al., 2007), show a strictly increasing signature identical to that of samples carbonised at temperatures less than $450^{\circ} \mathrm{C}$ from the two series of Eucalyptus. From spectrophotometric and geochemical points of view (Fig. 1), the signature of these two standards is rather close to immature coals such as lignite.

A parallel between this change in Std slope signals and previous results from FTIR performed on coals may be drawn for low wavenumbers $\left(900-700 \mathrm{~cm}^{-1}\right)$. Although this region also contains deformations related to $\mathrm{CH}_{2}$ rocking vibrations (e.g. at 772 and $834 \mathrm{~cm}^{-1}$, Kuehn et al., 1982; Guilliano et al., 1988), this range is classically assigned to aromatic $\mathrm{CH}$ out-ofplane bending modes, which can shift according to the number of adjacent hydrogens indicating the substitution degree of aromatic rings (e.g. Guilliano et al., 1988). In particular, deformations occurring at less than $800 \mathrm{~cm}^{-1}$ are assigned to the $\mathrm{CH}$ vibrations of low substituted aromatic rings (three to four adjacent hydrogens), while those observed between 900 and $800 \mathrm{~cm}^{-1}$ correspond to a higher degree of substitution of aromatic rings (one to two adjacent hydrogens; e.g. Sobkowiak et al., 1984; Guilliano et al., 1988). Studies have shown a positive correlation between the thermal evolution of coal and the intensity of absorbance peaks in the $900-$ to $700-\mathrm{cm}^{-1}$ region (e.g. Kuehn et al., 1982; Sobkowiak et al., 1984; Galvez et al., 2002) followed by a progressive decrease in the degree of substitution of polyaromatic cycles (Guilliano et al., 1988).
This increase is also concomitant to that of the ratio of aromatic/aliphatic $\mathrm{CH}$ (i.e. hydrogen linked by aromatic rings vs. aliphatic molecules; Riesser et al., 1984). When TOC values exceed $90.0 \mathrm{wt} . \%$, it is assumed that hydrogen is mainly distributed on the aromatic planes (Riesser et al., 1984) and vitrinite reflectance measurements reach $1.80-2.00 \%$ (see Tab. 1). For these vitrinite reflectance values and therefore an $(\mathrm{H} / \mathrm{C})_{\text {at }}$ ratio close to 0.50 , these chemical changes due to temperature are also accompanied by a major microtextural change in coal related to the loss of heteroatoms and causing a preferential molecular orientation of poly-aromatic layers (i.e. the basic structural unit (BSU) of coals and cokes; see Rouzaud and Oberlin, 1990). This suggests that the change of spectrophotometric signal slope in the 600 - to 700 -nm region, which occurs in the vicinity of a $(\mathrm{H} / \mathrm{C})_{\text {at }}$ ratio close to 0.50 , can be explained by the increase in aromaticity, the loss of substitution degree of aromatic rings and the local orientation in parallel of BSU within all carbonaceous materials.

\subsection{Matrix effect}

Applied to the total sediment, spectrophotometry incorporates all colour variations in the visible range, so not only changes in organic matter (see above), but also in mineral matter. We tested the matrix effect on OM spectrophotometry signals by performing a series of dilutions of the A20 coal sample in chalk and illite for TOC ranging from 80.0 to $0.1 \mathrm{wt} . \%$ (Fig. 6).

When the A20 sample is diluted in illite, the FDS signature shows an overall decline of the spectrum as the concentration of coal increases. This decrease in the slope of the spectra is not linear since spectrophotometry sensitivity is greater when concentrations of OM are low (Fig. 6). Std spectra show that the increasing imprint of FOC signature is acquired up to the TOC value of $40.0 \mathrm{wt} . \%$, i.e. for low to moderate dilutions. For higher dilutions, the OM occurrence is attested in FDS signatures, but the type of OM cannot be determined (i.e. the three populations identified above). 

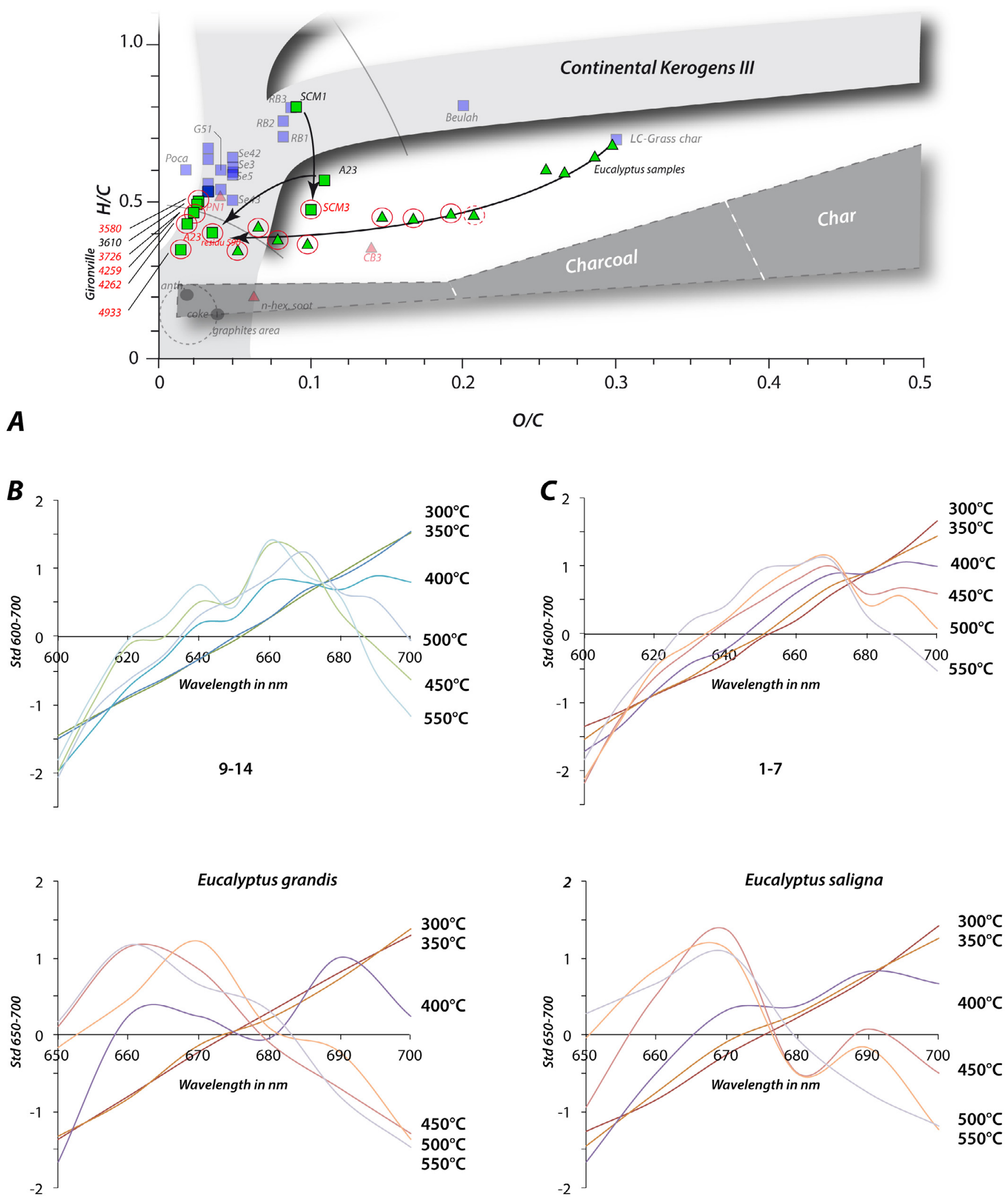

Fig. 5. Upper part: Distribution of the three sets of samples and the experimental samples from Trompovski et al. (2005) in a Van Krevelen diagram. Red circles correspond to samples characterised by a decreasing Std signals, green triangles corresponds to samples from Tompowsky et al. (2005), green squares to the three sets of samples discussed in text. These later samples were subjected to a progressive pyrolysis as highlighted by the lowering of $(\mathrm{H} / \mathrm{C})_{\text {at. }}$ and $(\mathrm{O} / \mathrm{C})_{\text {at. }}$ ratio values. A) 1-7 samples correspond to the Eucalyptus grandis species and B) 9-14 to Eucalyptus saligna. Both species show a transition in Std signatures in the Std600/750 (upper part) that is more distinguishable in CR650/700 (Lower part) with a shift that occurs around $400^{\circ} \mathrm{C}$ where the spectra increasing trend disappears. 

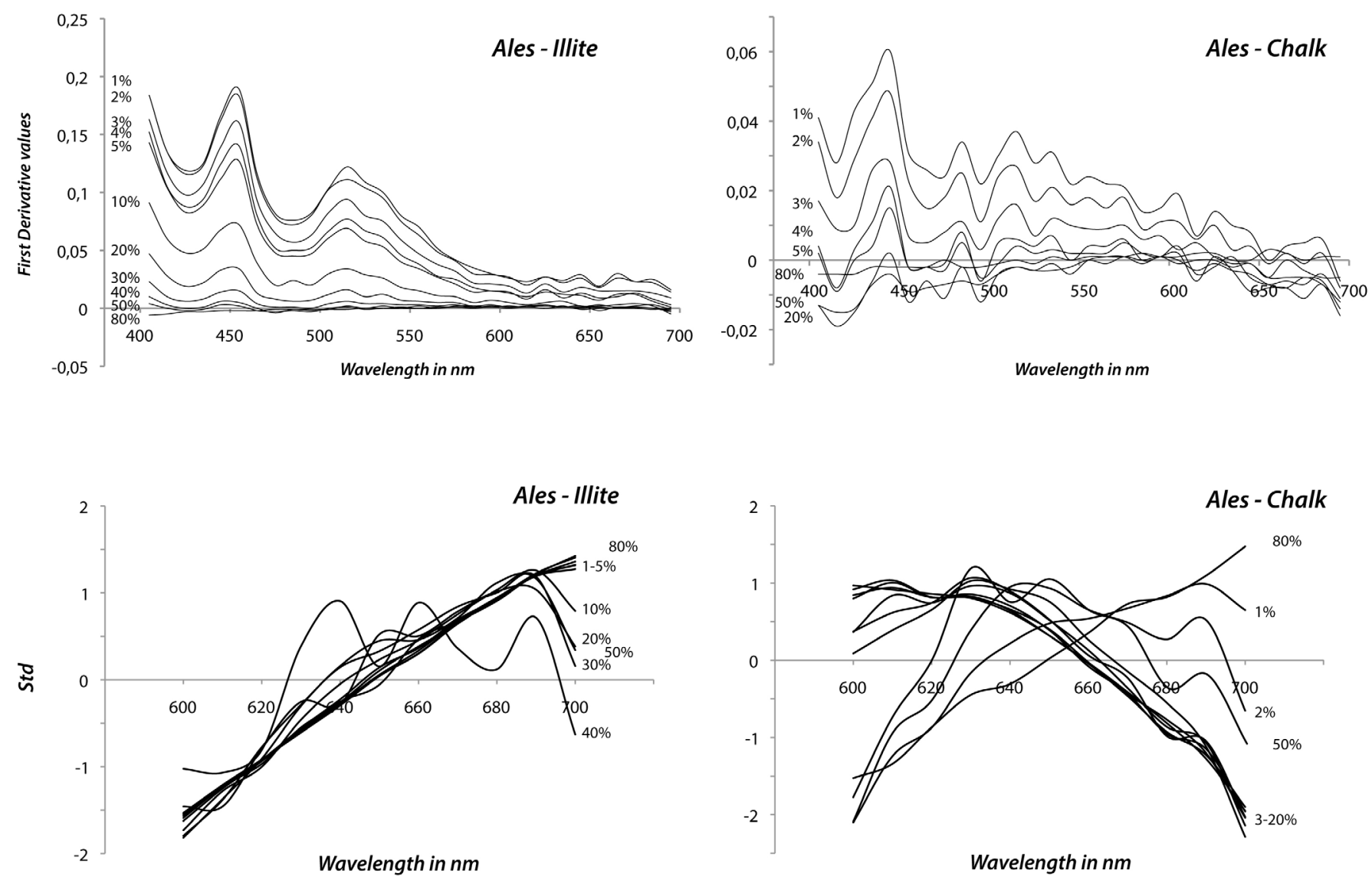

Fig. 6. Evolution of dilutions highlighted by FDS (upper part) and Std (lower part) for A20 sample (Ales coalfield) in illite (left) and chalk (right) matrix.

When the A20 sample is diluted in chalk, the FDS signature is more complex than that seen with illite. The sensitivity of spectrophotometry is greater at low coal concentrations, while when the concentrations increase, the amplitude variations diminish. The Std spectrum decreases in amplitude until a TOC equal to $20.0 \mathrm{wt} . \%$, then the pattern changes to emphasise the detection of OM. In turn, Std spectra indicate that the FOC signature becomes important in the signal around $20.0 \mathrm{wt} . \%$.

These results clearly indicate that the effect of the matrix is very important and depends on its nature. For type III OM, the amplitudes of the FDS or CStd spectra are complex and cannot be used to identify the origin of the OM or to evaluate their concentration. Other OM need to be tested. However, it is important to note that the influence of FOM and certainly BCM on spectrocolorimetric signatures is detected very quickly, especially for TOC lower than $5 \mathrm{wt} . \%$ for illite, but still varies according to the matrix. The sensitivity of the spectrophotometric signatures is less when the FOC is included in the illite matrix.

\subsection{New perspectives for TOC calibration}

Although FDS and Std are complex to analyse, the L* parameter, conventionally used as greyscale (black/white), quantifies the brightness (expressed in \%) of sediments. This parameter is particularly interesting in the context of a binary mixture (i.e. $\mathrm{OM}+$ mineral). Correlated with $\mathrm{TOC}$, it is possible to establish calibration curves in order to predict the TOC content. For the A20 coal sample, the diagram shows two different dilution curves according to illite and chalk matrices (Fig. 7). These curves confirm the obvious link between the colour variations and the change in TOC values for a given matrix. Thus, for low TOC values, coal diluted in illite is $15 \%$ darker than when diluted in chalk. However, this difference between the calibration curves is not constant and decreases even more as the TOC content of a sample tends towards the pole of organic matter (carbon, i.e. lower L* values, see Debret et al., 2011). Calibration curves show that this method is particularly accurate for low TOC content $(8 \%$ in material reflectance equivalent to a TOC of $4.0 \mathrm{wt} . \%$ for chalk and illite; see Fig. 7), but remains less accurate for high concentrations, especially when the matrix is darker. This means that the $\mathrm{L}^{*}$ parameter is a good indicator of the TOC content, especially for low TOC values and clear matrices such as chalk.

These matrix effects (colour, dilution) were also validated by Westphalian coal samples taken from the Gironville 101 borehole (samples from cuttings, Paris Basin). The distribution of points in Figure 7 confirms the $\mathrm{L}^{*}$ parameter as a reliable proxy of TOC, especially when values are lower than $20.0 \mathrm{wt}$. $\%$. This $20 \%$ threshold of TOC disappears once the mixture contains a clear matrix $\left(\mathrm{L}^{*}=75 \%\right)$. However, when the study concerns a natural sample, such as those from a sedimentary core, the limit conditions to use these calibration curves is that 


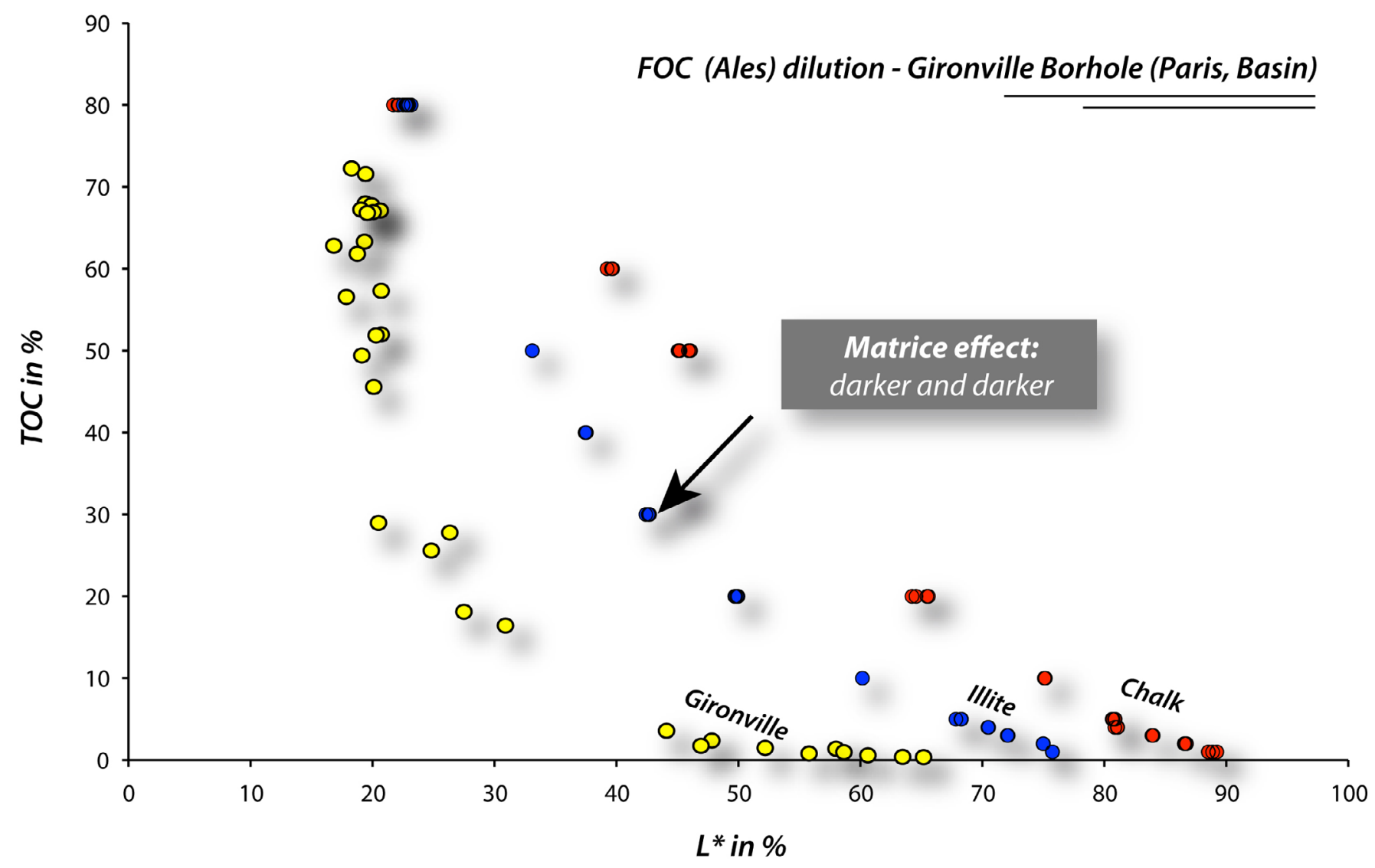

Fig. 7. L* (black/white) vs. TOC: experimental dilution of Ales FOC in illite and chalk matrix and natural dilution of a serie of westphalian coals from Gironville borehole 101 (Paris Basin)

the mineral matrix remains constant throughout the examined section, as for this core. In the case of non-homogeneous matrices, the FDS could distinguish different lithological facies which each have their own calibration curve.

\section{Conclusion}

Spectrophotometry is non-destructive and allows fast data acquisition. This method has been tested on standards, artificial and natural samples of geological coals and charred materials of anthropogenic origin. Spectral signatures have been highlighted by the Standardized method and characterised by the intensity of the carbonisation process recorded either naturally during burial (from diagenesis to metagenesis, or even slight metamorphism), during combustion or experimentally during pyrolysis. Under experimental conditions (laboratory oven), a maximum temperature of roughly $450{ }^{\circ} \mathrm{C}$ marks the change of the Std spectral signature (with respect to pyrolysis duration). In a Van Krevelen diagram, this signature shift corresponds to an $(\mathrm{H} / \mathrm{C})_{\text {at }}$ ratio value close to 0.50 , related to the increase in aromaticity consecutive to a loss of heteroatoms. For synthetic carbon samples, this step of carbonization is known as semi-coke stage. For geological samples (FOM), this limit corresponds to the end of the oil window.

Dilutions between FOM (coal) and the mineral matrix (chalk and illite) emphasise the impact of FOM on spectrophotometric signatures. This impact is detected more easily (i.e. when TOC values are low) if the matrix is clear, whatever methods are used (FDS, Std).

In a natural context, involving Paleozoic coals and dark mineral matrix (Gironville 101 borehole), it is finally possible to provide calibration curves connecting the $\mathrm{L}^{*}$ parameter and the TOC content where the value of $\mathrm{L}^{*}$ is extremely sensitive to low TOC values. Although in the case of dark matrix, the $\mathrm{L} * /$ TOC relation is limited to TOC values less than $20.0 \mathrm{wt} . \%$, this threshold disappears quickly when the matrices are lighter. The production of these charts seems promising for a rapid assessment of the TOC content in thick sedimentary sequences provided that the mineral matrix, previously identified by the FDS, are homogeneous. After further calibrations, spectrophotometry would be a very simple, fast and attractive method to detect low concentrations of TOC in rocks and sediments and can be useful in selecting samples for further geochemical analyses.

Acknowledgement. The spectrophotometer was financed by Haute-Normandie region through the CNRS Research Federation 3730 SCALE (SCiences Apliquées à L'Environnement). M. Desmet is acknowledged for technical support and valuable advice. Authors would also thank the International Steering Committee of Black Carbon References Materials (in particular Pr. MWI Schmidt, Univ. Zurich, Switzerland and Dr. DM Smith, Univ. Denver, USA) and VM Benites (Embrapa Solos, Rio Janeiro, Brazil) who have provided the two series of carbonised samples of Eucalyptus. 


\section{References}

Akhter MS, Chughtai AR, Smith DM. 1985. The structure of hexane soot I: spectroscopic studies. Appl Spectrosc 39: 143-153.

Alpern B. 1966. Un exemple intéressant de houillification dans le bassin Lorrain et ses prolongements. In: Advances in Organic Geochemistry, 1964. London: Pergamon Press, pp. 129-146.

Balsam WL, Damuth JE. Schneider RR. 1997. Comparison of shipboard $v s$. shorebased spectral data from Amazon Fan cores: implications for interpreting sediment composition. Ocean Drilling Program Science 155s: 193-215.

Bernal JD. 1924. The structure of graphite. Proceedings of the Royal Society of London. Series A, Containing Papers of a Mathematical and Physical Character 106(740): 749-773.

Bordenave ML, Espitalié J, Leplat P, Oudin JL, Vandenbroucke M. 1993. Screening techniques for source rock evaluation. In: Bordenave, eds. Applied petroleum geochemistry. Paris: Technip, pp. 217-278.

Burdige DJ. 2007. Preservation of organic matter in marine sediments: controls, mechanisms, and an imbalance in sediment organic carbon budgets? Chem Rev 107: 467-485.

Busch A, Gensterblum Y, Krooss BM. 2003. Methane and $\mathrm{CO}_{2}$ sorption and desorption measurements on dry Argonne premium coals: pure components and mixtures. Int J Coal Geol 55: 205-224.

Chapman MR, Shackleton NJ. 1998. What level of resolution is attainable in a deep-sea core: results of a spectrophotometer study. Paleoceanography 13: 311-315.

Copard Y. 2002. Altération diagénétique et post-diagénétique (thermicité, oxydation) des charbons carbonifères du Massif Central français (Saint Étienne, Graissessac et autres lieux). Doctoral thesis, University of Orléans, $306 \mathrm{p}$.

Copard Y, Disnar JR, Becq-Giraudon JF, Boussafir M. 2000. Evidence and effects of fluid circulation on organic matter in intramontane coalfields (Massif Central, France). Int J Coal Geol 44: 49-68.

Copard Y, Disnar JR, Becq-Giraudon JF. 2002. Erroneous maturity assessment given by Rock-Eval parameters (Tmax and HI) on highly mature weathered coals. Int J Coal Geol 49: 57-65.

Copard Y, Disnar JR, Becq-Giraudon JF, Laggoun-Défarge F. 2004. Erroneous coal maturity assessment caused by low temperature oxidation. Int J Coal Geol 58: 171-180.

Copard Y, Di-Giovanni C, Martaud T, Albéric P, Olivier JE. 2006. Using rock-eval 6 pyrolysis for tracking fossil organic carbon in modern environments: Implications for the roles of erosion and weathering. Earth Surf Proc Land 31: 135-153.

Copard Y, Amiotte-Suchet P, Di-Giovanni C. 2007. Storage and release of fossil organic carbon related to weathering of sedimentary rocks. Earth Planet Sci Let 258: 345-357.

Deaton BC, Nestell M, Balsam WL. 1996. Spectral reflectance of conodonts: a step toward quantitative colour alteration and thermal maturity indexes. AAPG Bulletin 80(7): 999-1007.

Debret M, Desmet M, Balsam W, Copard Y, Francus P, Laj C. 2006. Spectrophotometer analysis of holocene sediments from an anoxic fjord: Saanich Inlet, British Columbia, Canada. Mar Geol 229(12): 15-28. DOI: 10.1016/j.margeo.2006.01.005.

Debret M, Sebag D, Desmet M, Balsam W, Copard Y, Mourier B, et al. 2011. Spectrocolorimetric interpretation of sedimentary dynamics: The new "Q7/4 diagram". Earth Sci Rev 109(1-2): 1-19.

Di-Giovanni C, Disnar JR, Bichet V, Campy M. 1998. Sur la présence de matières organiques méso-cénozoïques dans des humus actuels (bassin de Chaillexon, Doubs, France). C R Acad Sci Paris 326: $553-559$.
Dickens AF, Gélinas Y, Masiello CA, Wakeham SG, Hedges JI. 2004. Reburial of fossil organic carbon in marine sediments. Nature 427: 336-339.

Ding G, Rice JA. 2012. Black carbon evaluation in natural organic matter samples using recoupled long-range dipolar dephasing solid-state 13C NMR. Geoderma 189-190: 381-387.

Duber S, Pusz S, Kwiecińska BK, Rouzaud JN. 2000. On the optically biaxial character and heterogeneity of anthracites. Int J Coal Geol 44: $227-250$.

Durand B. 1980. Kerogen. Paris: Technip.

Galvez A, Herlin-Boime N, Reynaud C, Clinard C, Rouzaud JN. 2002. Carbon particles from laser pyrolysis. Carbon 40: 2775 2789.

Graz Y, Di-Giovanni C, Copard Y, Laggoun-Défarge F, Boussafir M, Lallier Vergès E, et al. 2010. Quantitative palynofacies analysis as a new tool to study transfers of fossil organic matter in recent terrestrial environments. Int J Coal Geol 84: 49-62.

Graz Y, Di Giovanni C, Copard Y, Mathys N, Cras A, Marc V. 2012. Annual mechanical and chemical fluxes of fossil organic carbon exported by marly badlands areas: Example of the Draix experimental watersheds (Alpes-de-Haute-Provence, France). Earth Surf Proc Land 37: 1263-127.

Goldberg ED. 1985. Black carbon in the environment. New York: John Wiley.

Guilliano M, Mille G, Kister J, Muller JF. 1988. Étude des spectres IRTF de charbons français déminéralisés et de leurs macéraux. $J$ Chim Phys 85(10): 963-970.

Hammes K, Schmidt MWI, Smernik R, Currie LA, Ball WP, Nguyen TH, et al. 2007. Comparison of quantification methods to measure fire-derived (black / elemental) carbon in soils and sediments using reference materials from soil, water, sediment and the atmosphere. Global Biogeochem Cycles 21: GB3016. DOI: 10.1029/ 2006 GB002914.

Hammes K, Smernik RJ, Skjemstad JO, Schmidt MWI. 2008. Characterisation and evaluation of reference materials for black carbon analysis using elemental composition, colour, BET surface area and 13C NMR spectroscopy. App Geochem 23: 2113-2122.

Hedges JI, Eglinton G, Hatcher PG, Kirchman DL, Arnosti C, Derenne S, et al. 2000. The molecularly-uncharacterized component of nonliving organic matter in natural environments. Org Geochem 31: 945-958.

Ji J, Shen, J, Balsam W, Chen J, Liu L, Liu X. 2005. Asian Monsoon oscillations in the northeastern Qinghai-Tibet Plateau since the late glacial as interpreted from visible reflectance of Qinghai Lake sediments. Earth Planet Sci Lett 233, 61-70.

Knicker H. 2011. Pyrogenic organic matter in soils: its origin and occurrence, its chemistry and survival in soil environments. Quat Inter 243: 251-263.

Kuehn DW, Snyder DW, Davis A, Painter PC. 1982. Characterization of vitrinites concentrates, 1 . Fourier transform infrared spectra of coal. Fuel 61: 682-694.

Kuhlbusch TAJ. 1998. Black carbon in soils, sediments and ice cores. In: Meyers, ed. Encyclopedia of Environmental Analysis and Remediation. New York: John Wiley, pp. 813-823.

Kuo DTF, Van der Sande JB, Gschwend PM. 2013. Characterization of black carbon in geosorbents at the nanometer scale by STEMEDX elemental mapping. Org Geochem 56: 81-93. DOI: 10.1016/ j.orggeochem.2012.12.012.

Lafargue E, Marquis F, Pillot D. 1998. Rock-Eval 6 applications in hydrocarbon exploration, production and soil contamination studies. Rev I Fr Pétrol 53(4): 421-437. 
Lehmann J, Skjemstad J, Sohi S, Carter J, Barson M, Falloon P, et al. 2008. Australian climate-carbon cycle feedback reduced by soil black carbon. Naturegeoscience 1: 832-835.

Masiello CA, 2004. New directions in black carbon organic geochemistry. Mar Chem 92: 201-213.

Meredith W, Ascough PL, Bird MI, Large DJ, Snape CE, Sun Y, et al. 2012. Assessment of hydropyrolysis as a method for the quantification of black carbon using standard reference materials. Geochim Cosmochim Acta 97: 131-147.

Nichols JD. 1999. Resource assessment of selected Tertiary coal beds and zones in the Northern Rocky Mountains and Great Plains region. U.S. Geological Survey, Professional Paper, 1625-A, chapter WB, $14 \mathrm{p}$.

Noël H. 2001. Caractérisation et calibration des flux organiques sédimentaires dérivant du basin versant et de la production aquatique (Annecy, le Petit Lac) - Rôles respectifs de l'Homme et du Climat sur l'évolution des flux organiques au cours des 6000 dernières années. Doctoral thesis. University of Orléans, 279 p.

Noël H, Garbolino E, Brauer A, Lallier-Vergès E, De Beaulieu JL, Disnar JR. 2001. Human impact and soil erosion during the last $5000 \mathrm{yrs}$ as recorded in lacustrine sedimentary organic matter at Lac d'Annecy, the French Alps. J Paleolim 25: 229-244.

Oberlin A, Villey M, Combaz A. 1980. Influence of elemental composition on carbonization - pyrolyis of kerosene shale and kuckersite. Carbon 18: 347-353.

Poot A, Quika JTK, Veld H, Koelmans AA. 2009. Quantification methods of Black Carbon: Comparison of Rock-Eval analysis with traditional methods. J Chromato A 1216: 613-622.

Quénéa K, Derenne S, Gonzalez-Vila FJ, Mariotti A, Rouzaud JN, Largeau C. 2005. Study of the composition of the macromolecular refractory fraction from an acidic sandy forest soil (Landes de Gascogne, France) using chemical degradation and electron microscopy. Org Geochem 36: 1151-1162.

Raymond PA, Bauer JE. 2001. Riverine export of aged terrestrial organic matter to the North Atlantic Ocean. Nature 409: 497-500.

Riesser B, Starsinic M, Squires E, Davis A, Painter PC. 1984. Determination of aromatic and aliphatic $\mathrm{CH}$ groups in coal by FT-i.r. 2. Studies of coals and vitrinite concentrates. Fuel 63: 1253-1261.
Roth PJ, Lehndorff E, Brodowski S, Bornemann L, Sanchez-García L, Gustafsson O, et al. 2012. Differentiation of charcoal, soot and diagenetic carbon in soil: Method comparison and perspectives. Org Geochem 46: 66-75.

Rouzaud JN, Oberlin A. 1989. Structure, microtexture and optical properties of anthracene and saccharose-based carbons. Carbon 27: 517-529.

Rouzaud JN, Oberlin A. 1990. The characterization of coals and cokes by transmission electron microscopy. In: H Charcosset, B Nickel-Pepin-Donat, eds. Advanced methodologies in coal characterization. Coal Science and Technology 15: 311-355, Elsevier.

Rouzaud JN, Guechati N, Kister J, Conard J. 1991. Structural Characterization of coalification: example of Gironville borehole. Bull Soc géol Fr 162(2): 201-209.

Schmidt MWI, Noack AG. 2000. Black carbon in soils and sediments: analysis, distribution, and current challenges. Global Biogeochem. Cycles 14: 777-794.

Sobkowiak M, Reisser E, Given P, Painter PC. 1984. Determination of aromatic and aliphatic $\mathrm{CH}$ groups in coal by FT-i.r. 1. Studies of coal extracts. Fuel 63: 1245-1252.

Trompowsky PM, Benites VM, Madari BE, Pimenta AS, Hockaday WC, Hatcher PG. 2005. Characterization of humic like substances obtained by chemical oxidation of eucalyptus charcoal. Org Geochem 36: 480-1489.

Van Exem A, Debret M, Copard Y, Vannière B, Sabatier P, Marcotte S, et al. 2018. Hyperspectral core logging for fire reconstruction studies. Available from https://doi.org/10.1007/s10933-0170009-5.

Vannière B, Colombaroli D, Chapron E, Leroux A, Tinner W, Magny M. 2008. Climate versus human-driven fire regimes in Mediterranean landscapes: the Holocene record of Lago dell'Accesa (Tuscany, Italy). Quat Sci Rev 27(11): 1181-1196.

Vorres KS. 1990. The Argonne premium coal sample program. Energy \& Fuel 4: 420-426.

Wolf M, Lehndorff E, Wiesenberg GLB, Stockhausen M, Schwark L, Amelung W. 2013. Towards reconstruction of past fire regimes from geochemical analysis of charcoal. Org Geochem 55: 11-21.

Cite this article as: Debret M, Copard Y, Van Exem A, Bessereau G, Haeseler F, Rouzaud J-N. 2018. The color of refractory organic carbon, $B S G F$ - Earth Sciences Bulletin 189: 9. 